Journal of

Food and Nutrition

\title{
Porridge of Edible Nutsedges Produced in Togo: Traditional Production Pro- cesses and Socio-Economic Interest
}

Balbine Fagla Amoussou ${ }^{{ }^{*}}$, Dénis Aubin Kovobahou ${ }^{1}$, Victor Saturnin Bidossessi Houndji ${ }^{1}$, Zérach Jésugnon Noukpozounkou ${ }^{1}$, Mamatchi Mélila ${ }^{2}$, Nicodème Worou Chabi ${ }^{3}$, Sabiba Kou'santa Amouzou ${ }^{2}$, Paulin Azokpo$\mathbf{t a}^{1}$

${ }^{1}$ Laboratory of Food Physico-Chemistry, Department of Nutrition and Food Sciences, Faculty of Agricultural Sciences, University of Abomey-Calavi, BP 526, Cotonou, Benin

${ }^{2}$ Department of Biochemistry and Nutrition, Faculty of Sciences, University of Lomé, 01BP: 1515 Lomé 01, Togo

${ }^{3}$ Laboratory of Research and Applied Biology, Department of Biochemistry, Molecular Biology and Nutrition at the Polytechnic School of Abomey-Calavi (EPAC), University of Abomey-Calavi BP 526, Cotonou, Benin

${ }^{*}$ Corresponding author: Balbine Fagla Amoussou, Laboratory of Food Physico-Chemistry, Department of Nutrition and Food Sciences, Faculty of Agricultural Sciences, University of Abomey-Calavi, BP 526, Cotonou, Benin; Email:-balbinak04@ yahoo.fr

Received Date: December 06, 2019 Accepted Date: January 18, 2020 Published Date: January 21, 2020

Citation: Balbine Fagla Amoussou (2020) Porridge of Edible Nutsedges Produced in Togo: Traditional Production Processes and Socio-Economic Interest. J Food Nutr 6: 1-12.

\begin{abstract}
The present study investigates the different traditional methods of producing porridge of edible nutsedges in Togo. This study aims mainly to contribute to food safety by edible nutsedge valorization. Its objectives are to determine the socio-economic characteristics of the production and marketing of edible nutsedges porridge in Togo and to investigate the traditional processes of edible nutsedges porridge production in the interest of their improvement. It consists of a series of technological follow-ups with producers of edible nutsedges porridge and consumer survey of said porridge by pre-established forms administered to the respondents. The production and distribution of edible nutsedges porridge are made by women aged between 25 and 43 years old. Producers may or may not incorporate other products such as milk and/or rice during production. As for the processes used for the production, it involves several unit operations, from sorting to cooking and conditioning, through washing, soaking, milling, wet sieving, and filtration or extraction. On the socio-economic level, this porridge production represents a lucrative activity for producers because it generates a rate of return of up to 1.77 divided between vending machines and producers.
\end{abstract}

This study revealed that different technological processes can lead to edible nutsedges porridge. Its commercialization makes it a profitable business. However, it will be possible to further improve the production processes with the use of insulated containers to better preserve its quality.

Keywords: Edible nutsedge; porridge production processes; producers and distributors; profitability

(C)2020 The Authors. Published by the JScholar under the terms of the Creative Commons Attribution License http://creativecommons.org/licenses/ by $/ 3.0 /$, which permits unrestricted use, provided the original author and source are credited. 


\section{Introduction}

Globally, the potato is the tuber produced in greater quantity. With sweet potato and cassava, it accounts for more than $90 \%$ of the tubers produced worldwide. Yams, taro and other tubers account for less than $8 \%$ of total production, with taro being the least commonly produced tuber [1]. The fight against poverty and food insecurity, in developing countries like Benin and Togo, is today a concern of the international community. This situation leads to populations in a situation of recurrent and growing vulnerability [2]. Among the least produced tubers, the use of edible nutsedges, an unconventional seed [3], can open the doors of food development to improve the food, environmental and economic situation of the countries. Edible nutsedge (Cyperus esculentusL.) is an herbaceous species of Cyperaceae family from the Mediterranean basin. Nutsedge produces tuberous seeds called almonds of ground tiger nuts [4,5]. Spain is the first world producer with 9,000 tons from 2,450 hectares of land in 2012 [6]. In Africa, the edible nutsedge was brought by the Arab wandering traders and now cultivated in various areas, especially in the Maghreb and Western Africa [7]. Unconventional seedlings, most of the family Cyperaceae has very little economic value with the exception of Cyperus papyrus which is used in the manufacture of paper and Cyperus esculentusL. (nutsedge) which is edible [3]. Cyperus esculenstus is a perennial species of the family Cyperaceae [8]. In addition, the revaluation of indigenous technologies of this tuber will prevent dislocation of traditional societies, a crisis in rural areas and a loss of food self-sufficiency [9]. The production of porridge is the form of recovery most observed in Togo where this porridge is commonly called in Ewe (a national language in Togo) "EFFIO ZOGBON". This porridge is food produced according to traditional technology by women and is frequently consumed in any period. However, despite the socio-economic importance of the edible nutsedges porridge and the establishment of several production sites in Togo and in some countries of the sub-region such as Benin, no study has been devoted to this product. It is, therefore, necessary to identify and evaluate the traditional methods of producing said slurry in order to find the advantages of recovery axes. It is with this in mind that this study was conducted. This study aims mainly to contribute to the food safety by edible nutsedges valorization, determining the socio-economic characteristics of the production and marketing of edible nutsedges porridge in Togo and investigating the traditional processes of the production of this porridge in the interest of its improvement.

\section{Material and Method}

\section{Study design}

A descriptive, cross-sectional study design was conducted for the present study.

\section{Research settings}

The present study was conducted in Togo in the maritime region whose coordinates are $6^{\circ} 08^{\prime} 14^{\prime \prime}$ North, $1^{\circ} 12^{\prime} 45^{\prime \prime}$ East. The population of the maritime region of Togo amounts to 837437 inhabitants in 2010 with a density of 9305 inhabitants/ $\mathrm{km}^{2}$ [10]. The study is conducted mainly in the prefectures of AGOE-NYIVE, GULF, and LACS. The study area is presented in Figure 1.

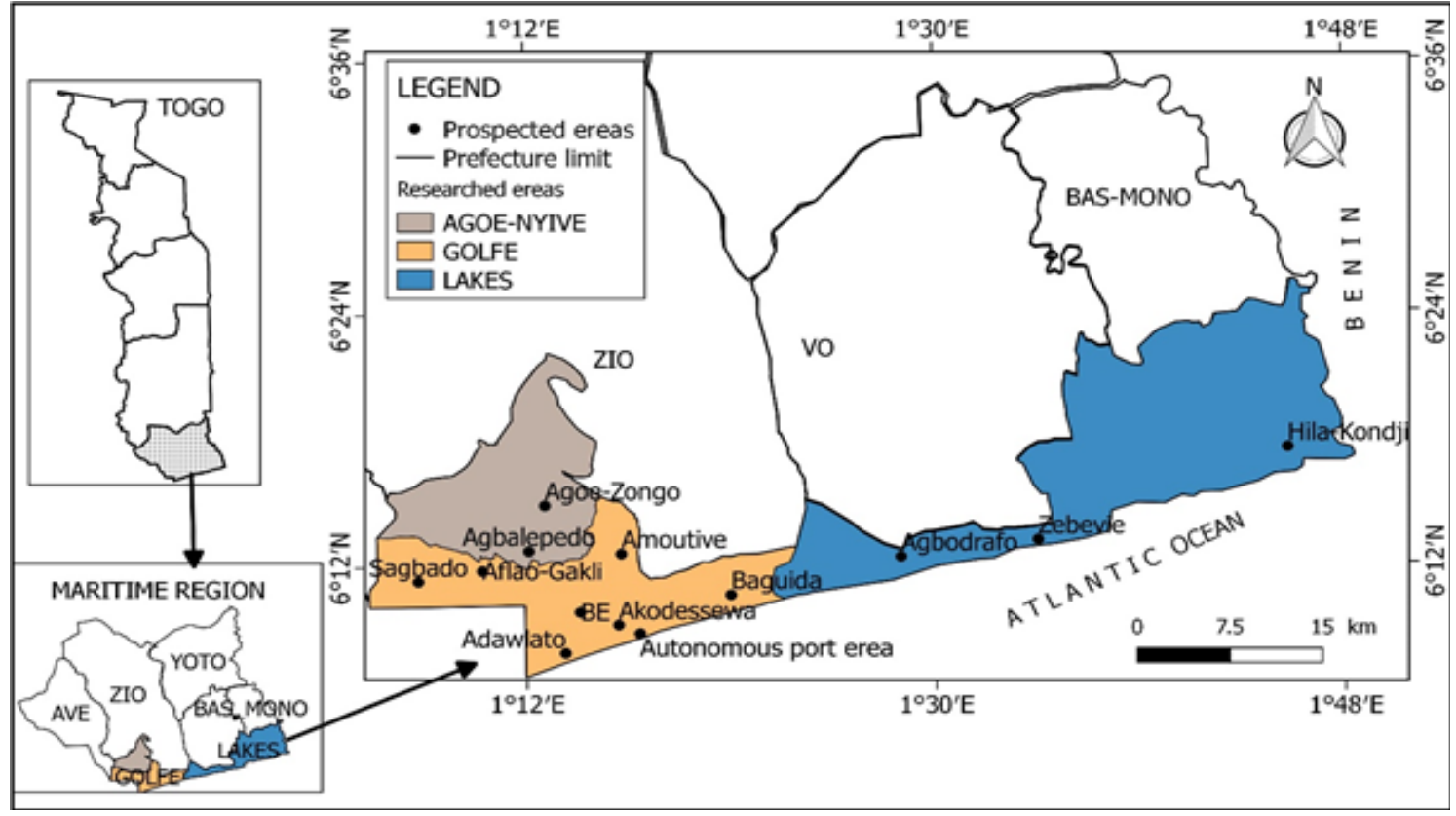

Figure 1: Map of the study area 


\section{Study population}

Producers of edible nutsedges porridge in Togo.

\section{Sample size and technical sampling}

The manufacturing process of this slurry was monitored and diagnosed with twelve producers including 3 in the prefecture of AGOE-NYIVE, 7 in the prefecture of GOLF and 2 in the prefecture of LACS in order to perceive the variability.

\section{Study plan}

The methodology adopted for the realization of this study is articulated around two points: a technological survey and a consumer survey phase. Since this involves investigating traditional methods of producing porridge, edible nutsedge cultivars have been purchased to facilitate the production of porridge. These cultivars were used to produce the various porridges of nutsedges. A literature search followed by a pre-survey of certain resource persons intervening or having previously intervened in the nutsedges industry was made. The purpose of this pre-survey was to identify the edible nutsedges processing units as well as the various nutsedges byproducts obtained in these units. At the end of this activity, a sample of twelve porridge production units was selected for a technology survey that was the second step in this study. These units were chosen because they had been in existence for at least two years, and they have proven production and data experience that is reliable and useful for this study. The objective of this survey was to characterize the different technologies of production of the edible nutsedge-based porridge and the different types of equipment used for production. It should be noted that special emphasis has been placed on the raw materials used for the production of this porridge. The choice of survey sites was made in a reasoned manner. The three prefectures were chosen because they are localities where the traditional technology of production of this porridge meets. The survey was aimed at producers of nutsedge products derived from the various units selected. The data were collected using a maintenance guide on the socio-cultural aspects of production, the raw materials used and the factors determining their choice, the nature and succession of unit operations, the characteristics of the equipment and the operating parameters (temperatures, times, masses and volumes of raw materials and products). The survey enabled the development of the production technology diagram of each derived product in the study area and the sampling of each by-product for laboratory analysis. For the material balance, the data of four production tests recorded in these units were considered.

\section{The equipment used during investigations}

A MASTECH brand probe thermometer used for taking the porridge cooking steam temperature; a stopwatch for recording durations of unit operations; a weighing scale of $5 \mathrm{~kg}$ and a precision of $50 \mathrm{~g}$ for the weighing of raw materials.

\section{Results and Discussion Sample Size}

The surveys covered 12 female producers randomly selected and a total of 113 consumers. Pre-established questionnaires were used to collect information from respondents.

\begin{tabular}{|l|l|l|l|}
\hline $\begin{array}{l}\text { Locality } \\
\text { (Prefectures) }\end{array}$ & $\begin{array}{l}\text { Number of } \\
\text { producers } \\
\text { surveyed }\end{array}$ & $\begin{array}{l}\text { Number } \\
\text { distributors } \\
\text { surveyed }\end{array}$ & $\begin{array}{l}\text { Number of } \\
\text { consumers } \\
\text { surveyed }\end{array}$ \\
\hline AGOE-NYIVE & 3 & 7 & 36 \\
\hline GOLFE & 7 & 8 & 43 \\
\hline LACS & 2 & 4 & 34 \\
\hline Total & 12 & 19 & 113 \\
\hline
\end{tabular}

Table 1: Sample Size

\section{The different production processes}

From the analysis of the different preparation methods studied, it emerges that the production diagram of the nutsedge-type porridge can be subdivided into four main phases, namely: cleaning phase, phase of extraction and preparation of the starch and phase and cooking. Each of these phases is performed through one or more unit operations.

The technical differences observed between the production methods are mainly at the stage of extraction and preparation of the starch. These differences concern the duration of soaking of waste in the water, the fermentation or not before and/or after filtration, the degree of incorporation of other products such as milk and/or rice and the difference can also be noted by the absence of one of these unit operations. Thus, several production methods have been identified and are presented as follows in Table 2. According to Table 2, it is observed that sixunit operations are mandatory across different phases. These operations are cleaning (sorting and washing), soaking, milling, sieving, cooking, and conditioning. It was noted that the conditioning is not in isothermal containers [11] and the porridge is distributed as a street foods out in an itinerant way [12]. 


\begin{tabular}{|c|c|c|c|c|c|c|c|c|c|c|c|c|}
\hline & \multicolumn{11}{|c|}{ Unit operations } \\
\hline & & $\begin{array}{l}\text { Clean- } \\
\text { ing }\end{array}$ & Soaking & Milling & $\begin{array}{l}\text { Fermen- } \\
\text { tation }\end{array}$ & Sieving & \begin{tabular}{|l} 
Fer- \\
menta- \\
tion
\end{tabular} & $\begin{array}{l}\text { Incorpo- } \\
\text { ration of } \\
\text { rice }\end{array}$ & $\begin{array}{l}\text { Incorpo- } \\
\text { ration of } \\
\text { milk }\end{array}$ & $\begin{array}{l}\text { Cooking } \\
\text { and ad- } \\
\text { dition of } \\
\text { sugar and/ }\end{array}$ & $\begin{array}{l}\text { Incorpo- } \\
\text { ration of } \\
\text { milk }\end{array}$ & $\begin{array}{l}\text { Packag- } \\
\text { ing }\end{array}$ \\
\hline \multirow{12}{*}{ Methods } & 1 & + & + & + & + & + & - & + & + & + & - & + \\
\hline & 2 & + & + & + & + & + & - & + & + & + & - & + \\
\hline & 3 & + & + & + & - & + & + & + & + & + & - & + \\
\hline & 4 & + & + & + & + & + & - & + & + & + & - & + \\
\hline & 5 & + & + & + & - & + & - & + & - & + & + & + \\
\hline & 6 & + & + & + & - & + & - & + & + & + & - & + \\
\hline & 7 & + & + & + & + & + & - & - & - & + & + & + \\
\hline & 8 & + & + & + & - & + & + & + & - & + & - & + \\
\hline & 9 & + & + & + & - & + & - & - & - & + & - & + \\
\hline & 10 & + & + & + & + & + & - & - & + & + & - & + \\
\hline & 11 & + & + & + & - & + & - & - & - & + & + & + \\
\hline & 12 & + & + & + & + & + & - & + & - & + & + & + \\
\hline
\end{tabular}

Table 2: Presentation of the different unit operations according to various processes of production of the slurry containing

Fermentation and soaking operations play different roles. The soaking operation causes the humidification of the tubers, which facilitates their subsequent grinding by softening their texture and thus facilitates their grinding in order to have physical properties of starch grains easy to extract. The physical properties of starch grains affect the digestibility and ability of food plants (tubers, cereals) to be processed. This factor improves their digestibility and gives these varieties greater possibilities for direct use (in food) or indirect use (after processing). Processes such as cooking, dipping, and fermentation help to improve the digestibility of starch in foods [13]. The fermentation operation of the porridge pulp before the wet extraction and/or that of the filtrate after sieving induces organoleptic characteristics appreciated by the consumers. This factor improves their digestibility and gives these varieties greater possibilities for direct use (in food) or indirect use (after processing). Processes such as cooking, soaking, and fermentation help improve the digestibility of starch in foods and cooking the nutsedge tuber produces the same effects as the taro [13]. Follow-up cooking technology causes changes in the structure of taro starch [14]. Elkhalifa et al. [15] showed that fermentation significantly improves the in vitro digestibility of starch grains of sorghum. All the methods, although quite close to each other, use this fermentation, soaking of tubers differently with or without incorporation of other elements. Soaking, is a relatively variable operation compared to its duration, according to the producers. The milling of tubers is conditioned by the availability of the miller to grind tubers of nutsedge. This grind is then late in the night after the miller has finished grinding cereals. After milling, the producers keep the dough because of the late hour to begin sieving wet early in the morning. This explains the fermentation of the dough before sieving. They can also sift and store the filtrate, which will then be cooked early in the morning, in which case the filtrate ferments. Thus, the execution of this unit operation is dependent on the availability of the mill. In addition, depending on the preferences of each producer, ingredients are added during the preparation of the porridge to give it a certain characteristic. These ingredients, which vary from one producer to another, can be rice, sugar, milk, caramel, etc. Fermentation or not before and/or after filtration, the degree of incorporation of other products such as milk and/or rice may thus, vary from one process to another and the difference may be noted by the absence of these unit operations. The equipment used varies according to unit operations (Table 3 ).

\begin{tabular}{|c|c|c|}
\hline & & Equipment used \\
\hline \multirow{6}{*}{$\begin{array}{l}\text { Technological } \\
\text { Operations }\end{array}$} & Cleaning & Tray, bassin, basket \\
\hline & Soaking & Bassin \\
\hline & Milling & $\begin{array}{l}\text { Grinding mill grinding wheel, } \\
\text { motar }\end{array}$ \\
\hline & Wet sieving & $\begin{array}{l}\text { Sieve in nylon fabric (mesh less } \\
\text { than } 0,05 \mathrm{~mm} \text { ) }\end{array}$ \\
\hline & Cooking & Bassin \\
\hline & Packaging & $\begin{array}{l}\text { Sachets for packaging (packaging } \\
\text { of } 50 \text { and } 100 \text { FCFA) }\end{array}$ \\
\hline
\end{tabular}

Table 3: Equipment used during the preparation of the porridges. F CFA: Franc of French Colonies of Africa 
At the other stages of production (cleaning, cooking, packaging), the differences between the methods of preparation are less noticeable. In all the processes, the cleaning of the grains is first dry by sorting and/or by winnowing, then water immersion and trituration to finish the draining. Finally, with regard to cooking, it usually takes place immediately after wet sieving in the morning and precedes the packaging for sale by the vending machines.

Table 4 shows the evaluation of technological operations. It also makes it possible to identify some critical points in the production processes of porridge especially at the time of its packaging for sale. Indeed, the variation of the temperature which could fall down to $52{ }^{\circ} \mathrm{C}$ (Table 4) implies a possibility of contamination by pathogenic germs, concomitantly with air bubbles (Photo 1) that can exist inside the packaging. This situation could be minimized if female producers used isothermal taps (Figure 2).

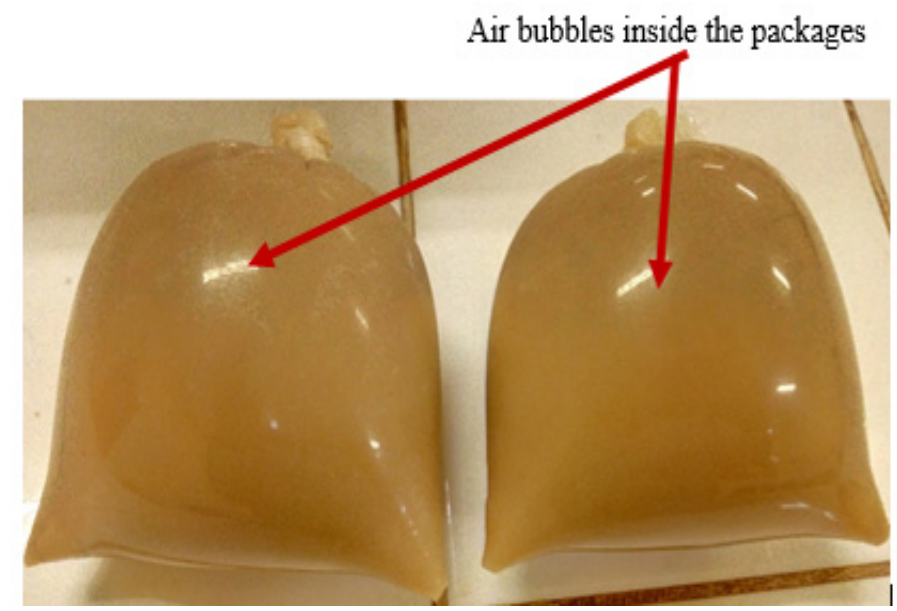

Photo 1: Packaging of porridge

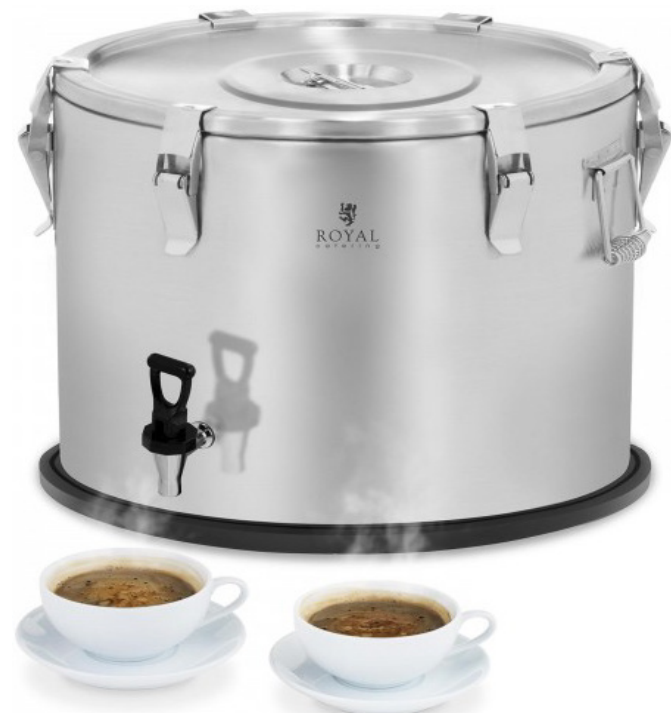

Figure 2:_An example of isothermal container withtap ${ }^{[1]}$

\begin{tabular}{|c|c|c|c|}
\hline & & $\begin{array}{l}\text { Duration of } \\
\text { operations }\end{array}$ & $\begin{array}{l}\text { Temperature of } \\
\text { operations }\end{array}$ \\
\hline \multirow{8}{*}{$\begin{array}{l}\text { Technolog- } \\
\text { ical opera- } \\
\text { tions }\end{array}$} & Sorting & $20-30$ minutes & $\begin{array}{l}\text { Ambiente } \\
\left(27-34^{\circ} \mathrm{C}\right)\end{array}$ \\
\hline & Washing & 10 - 15 minutes & $\begin{array}{l}\text { Ambiente } \\
\left(27-34^{\circ} \mathrm{C}\right)\end{array}$ \\
\hline & Soaking & $02-16$ heures & $\begin{array}{l}\text { Ambiente } \\
\left(27-34^{\circ} \mathrm{C}\right)\end{array}$ \\
\hline & Fine grinding & $07-12$ minutes & $\begin{array}{l}\text { Ambiente } \\
\left(27-34^{\circ} \mathrm{C}\right)\end{array}$ \\
\hline & Fermentation & $02-8$ heures & $\begin{array}{l}\text { Ambiente } \\
\left(27-34^{\circ} \mathrm{C}\right)\end{array}$ \\
\hline & Wet sieving & $30-40$ minutes & $\begin{array}{l}\text { Ambiente } \\
\left(27-34^{\circ} \mathrm{C}\right)\end{array}$ \\
\hline & Cooking & 55 - 90 minutes & $98-100^{\circ} \mathrm{C}$ \\
\hline & Packaging & $90-120$ minutes & $52-100^{\circ} \mathrm{C}$ \\
\hline
\end{tabular}

Table 4: Evaluations of some technological parameters for $3 \mathrm{~kg}$ of waste

Soaking is a complementary operation of the washing. It is made in plastic basins without lid with a variable duration between 2 and 16 hours depending on the producers. This variable duration can be explained by the time between the acquisition of the waste and the availability for milling. It softens the tubers and facilitates their milling. Milling of nutsedge tubers is done at the grinding wheel mill with a variable duration depending on the quantity to grind. A slight increase in the temperature of the ground product could be explained by the friction and wear of the grinding wheels in contact with the tubers. This situation may result in contamination of the product with metals from the grinding wheels. Sifting depends on both the amount of product processed and the size of the sieve mesh. The sieves used are nylon webs with a mesh size of less than 0.05 millimeters. Sifting allows the starch to be suspended in water. Fermentation takes place at room temperature $\left(27\right.$ to $\left.34^{\circ} \mathrm{C}\right)$ in basins without a lid. The fermentation is relatively light because it is not induced for a particular purpose. It may take place because of the time between the grinding and/or sieving, which takes place at night, cooking that is done early in the morning. Cooking takes about 55 to 90 minutes without adding water. Continuous mixing of the filtrate promotes, on the one hand, the heat transfers from the walls of the kettle and the adjacent layers towards the interior of the product and on the other hand, regular distribution of this heat. As this operation is performed, the product becomes encrusted and thickened with the evaporation of water. 
The additions are as follows:

- In the case of rice, it is soaked ground well and it is the ground product that is added to the dough of sieves during sieving.

- For milk, it is either added to the filtrate during cooking or after cooking, depending on the producers.

- The sugar is added by all the producers during cooking, as the caramel is added by most producers.

Some diagrams of productions according to the methods are presented as follows in Figures 3, 4 and 5.

Figure 3: Nutsedges porridge diagram without incorporation of cereals or

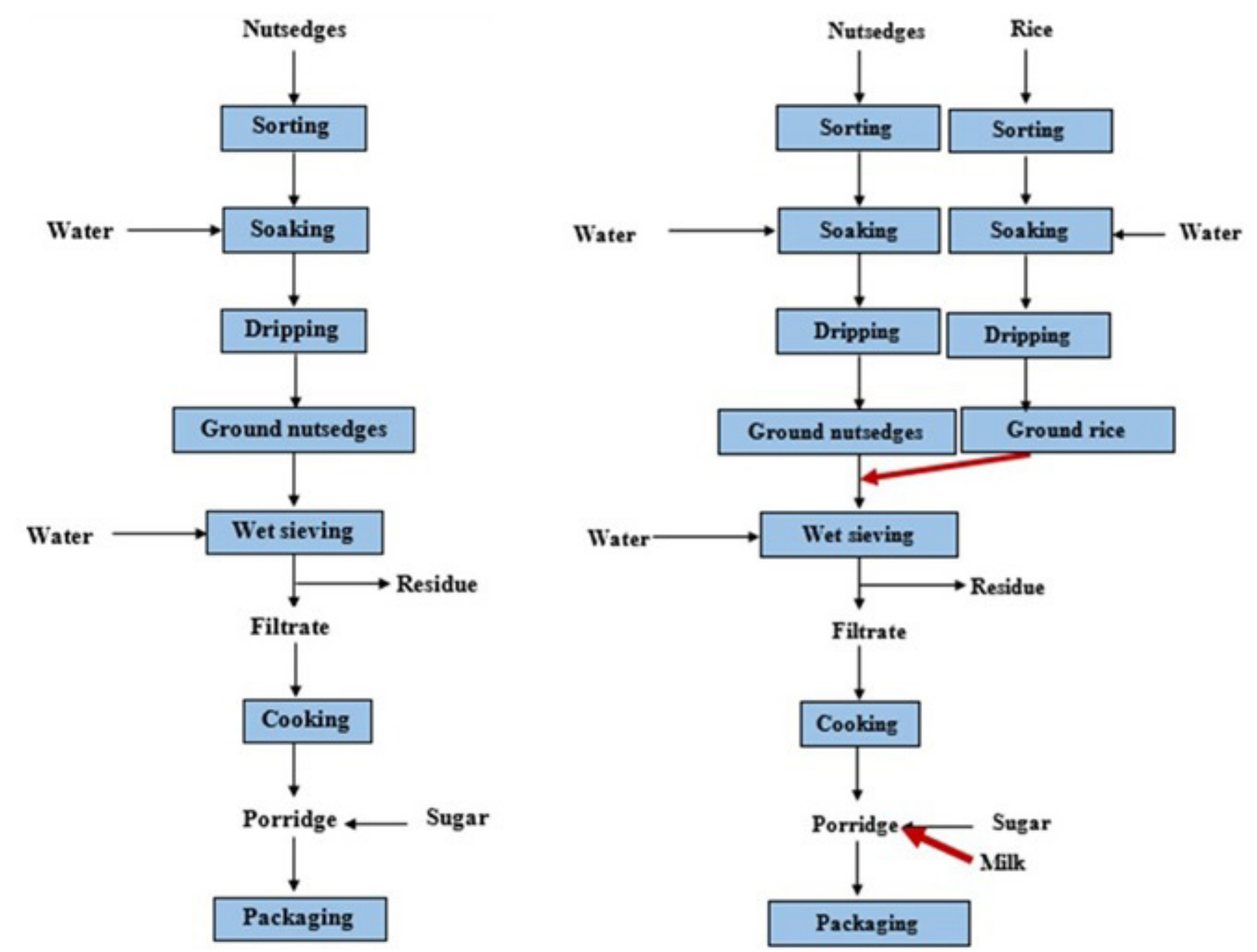

In the process of producing porridge, each unit operation is performed at a given stage and requires the involvement of raw materials. Table 5 shows the balance of materials and allows to say that the production of this porridge uses the usual ingredients which, with the trash allow this production. In addition, the production yield is greater than 1 and therefore the process used is good even though it could be improved.

Figure 4: Nutsedges porridge diagram with incorporation of rice and milk 


\begin{tabular}{|c|c|c|c|c|}
\hline Technological opération & $\begin{array}{l}\text { Quantity of incoming materi- } \\
\text { al of waste }(\mathrm{g})\end{array}$ & $\begin{array}{c}\text { Quantity of ingrédients } \\
(\mathrm{g})\end{array}$ & $\begin{array}{l}\text { Quantity of } \\
\text { material leav- } \\
\text { ing }(g)\end{array}$ & Yield \\
\hline Sorting & 4200 & - & 4000 & 0.95 \\
\hline Washing 1 & 4000 & Water: 7434 & 4045 & 1,01 \\
\hline Washing 2 & 4045 & Water: 7434 & 4100 & 1,01 \\
\hline Soaking & 4100 & Water: 7434 & 4360 & 1.06 \\
\hline Milling & 4360 & - & 4300 & 0.98 \\
\hline Wet sieving & 4300 & Water: 15000 & 19300 & 4.49 \\
\hline Cooking & 19300 & $\begin{array}{c}\text { Rice : } 0.25 \mathrm{~kg} \text {; Sugar : } 0.5 \\
\mathrm{~kg} \text {; } \\
\text { Milk : } 200 \mathrm{~g} \text {; caramel : } \\
0.25 \mathrm{~kg}\end{array}$ & 20000 & 1.03 \\
\hline Packaging & 2 package & - & - & - \\
\hline
\end{tabular}

Table 5: Material balance

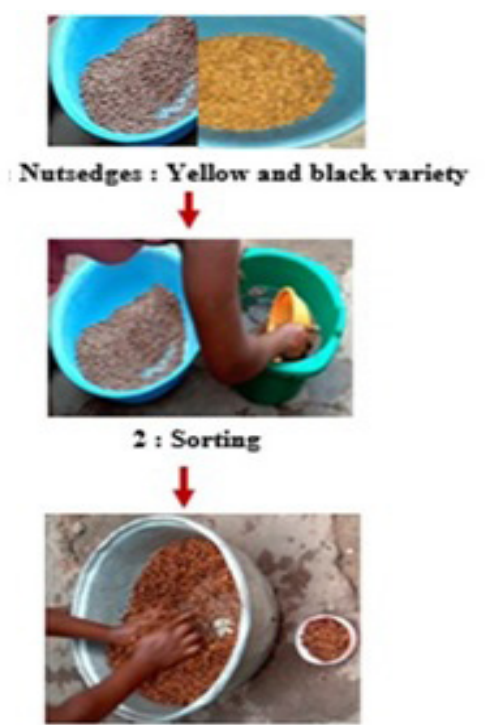

3: Washing

$\downarrow$

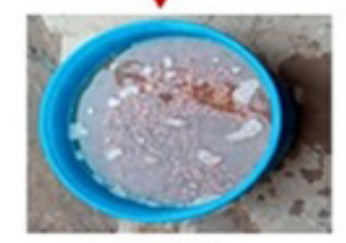

4 : Soaking

$\downarrow$

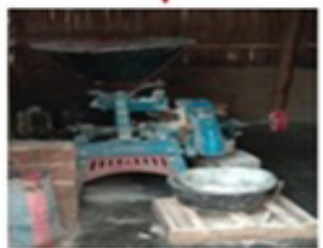

5: Mfilling

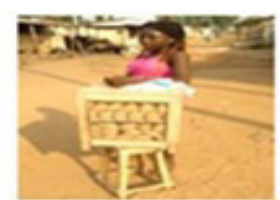

10 : Distributor of porridge

个

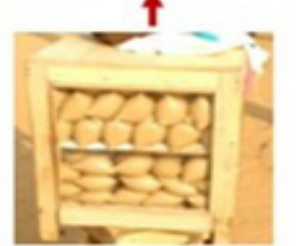

9: Porridge packaged

$\hat{\imath}$

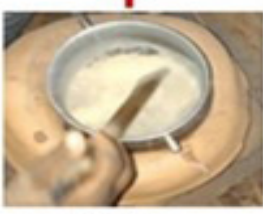

8 : Cooking

$\uparrow$

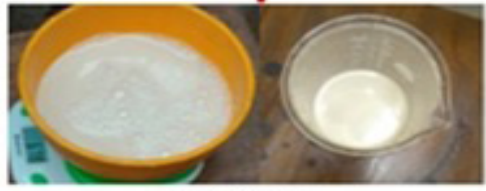

7: Filtrate

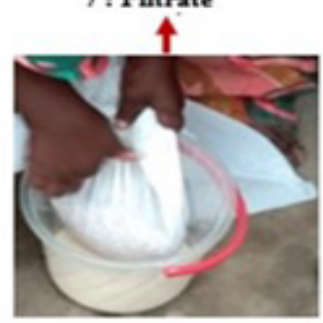

6: Wet sievine

Figure 5: Diagram with some unit operations of nutsedges porridge production 


\section{Actors in the production of nutsedge-based porridge}

These are the producers, distributors, and consumers of the edible nutsedge-based porridge.

\section{Ethnic actors}

In the maritime region and particularly in Lomé, there are several ethnic groups in Togo [10]. Thus, the respondents are from several ethnic groups in Togo. However, in our study, the EWE was the most represented at the consumer level with 39.8\% followed by MINA (24.8\%) and WATCHI (22.12\%). Ethnic groups such as KABYE and MOBA were also recorded with respectively $8 \%$ and $7 \%$ (Figure 6). This distribution is not surprising since the study area is that of EWE and MINA. In addition, the production of this porridge is more observed in the south of Togo dominated by the EWE, MINA and WATCHI peoples than in the North where we meet KABYE, MOBA and other ethnic groups such as KOTOKOLI.

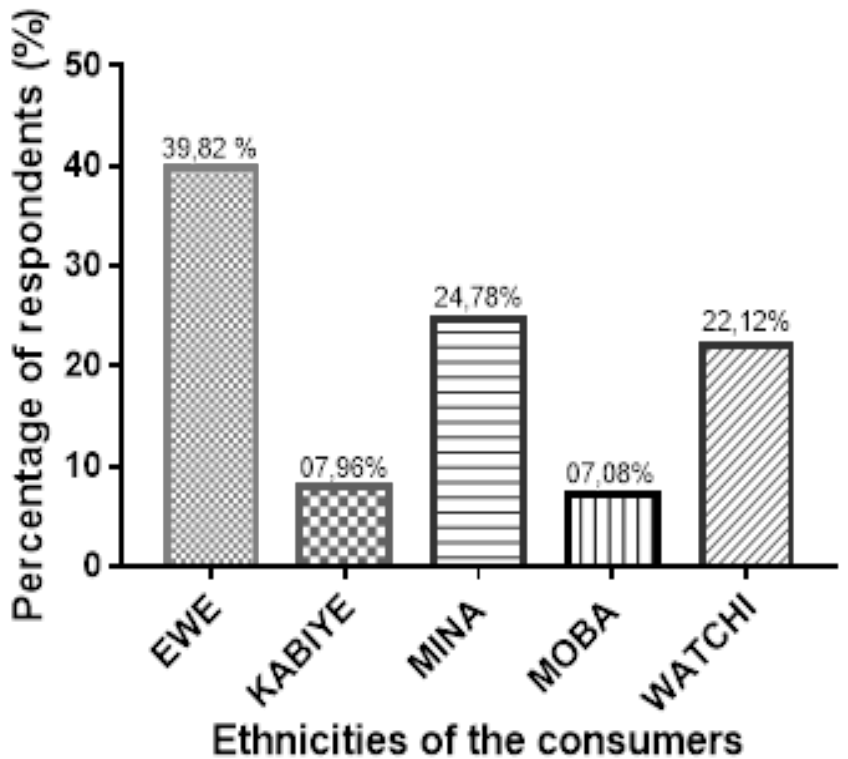

Figure 6: Distribution of consumers by ethnicity

In relation to production, it was noted that it concerns only the three ethnic groups of the South namely EWE, MINA, and WATCHI with respectively $58.3 \%, 25.00 \%$, and $16.7 \%$. This confirms that this porridge is more produced by southern peoples in our study area because no producer in our survey reported belonging to another ethnic group (Figure 7). However, it is possible to meet producers of this porridge belonging to other ethnic groups, our survey taking into account only 12 producers in all three prefectures surveyed.

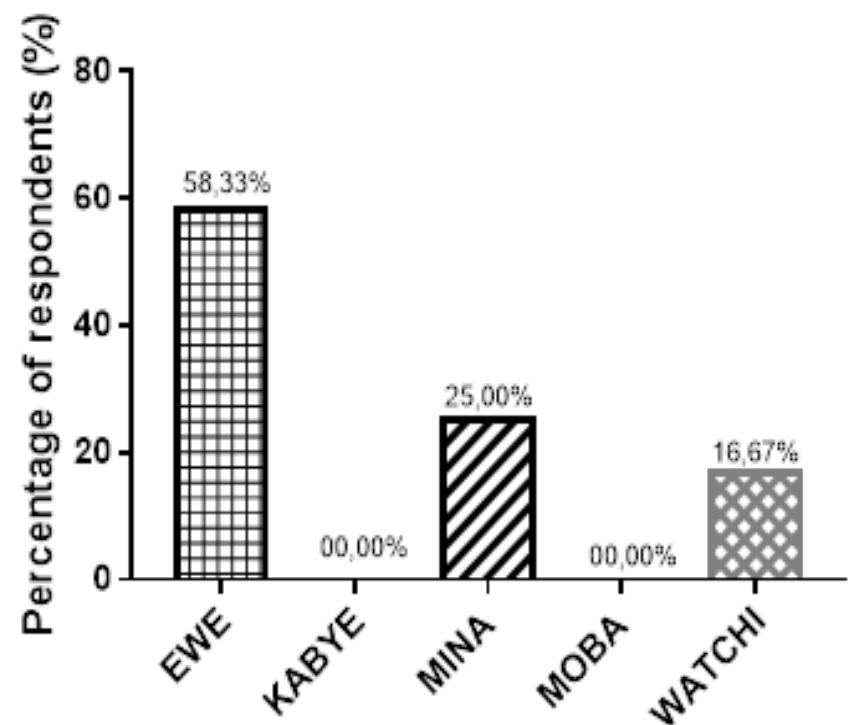

Ethnicities of the producers

Figure 7: Distribution of female producers by ethnicity

Moreover, contrary to production, the distribution of the porridge in our study area is also an activity of actresses from the North. Indeed, according to Figure 8 below, even if in the distribution or sale of porridge, the EWE is the majority with $36.8 \%$, we also note the KABYE, which are represented with the same proportion as MINA and WATCHI (15.8\%), as well as KOTOKOLI (10.5\%) and MOBA (5.3\%). This presence of KABYE, KOTOKOLI, and MOBA in the distribution of these porridges, is explained by the fact that they are the cleaning girls, coming from the North, in search of jobs, engaged by the producers for the distribution of their product.

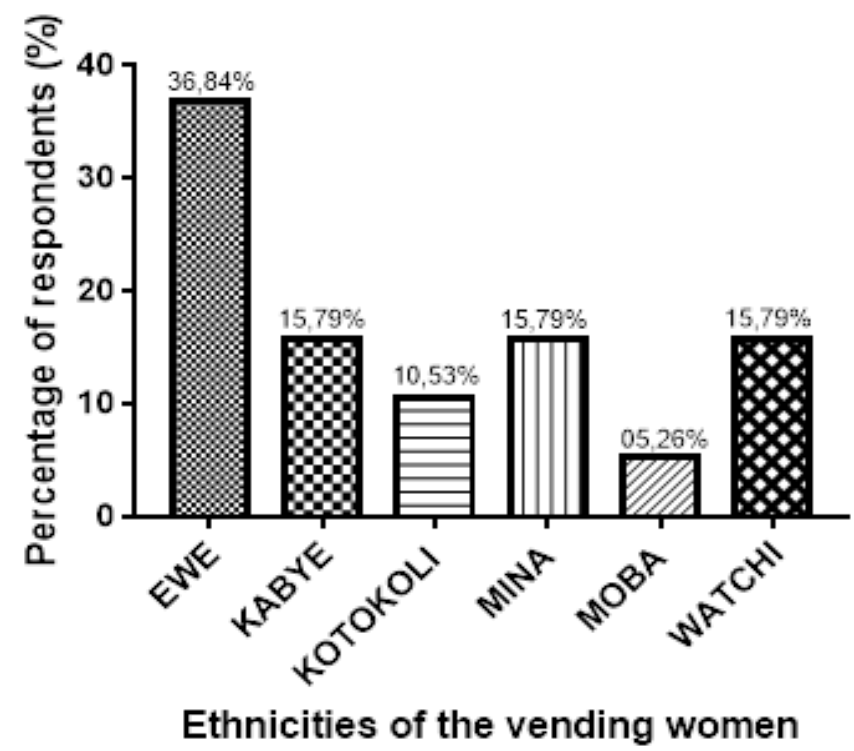

Figure 8: Distribution of porridge by ethnic group 


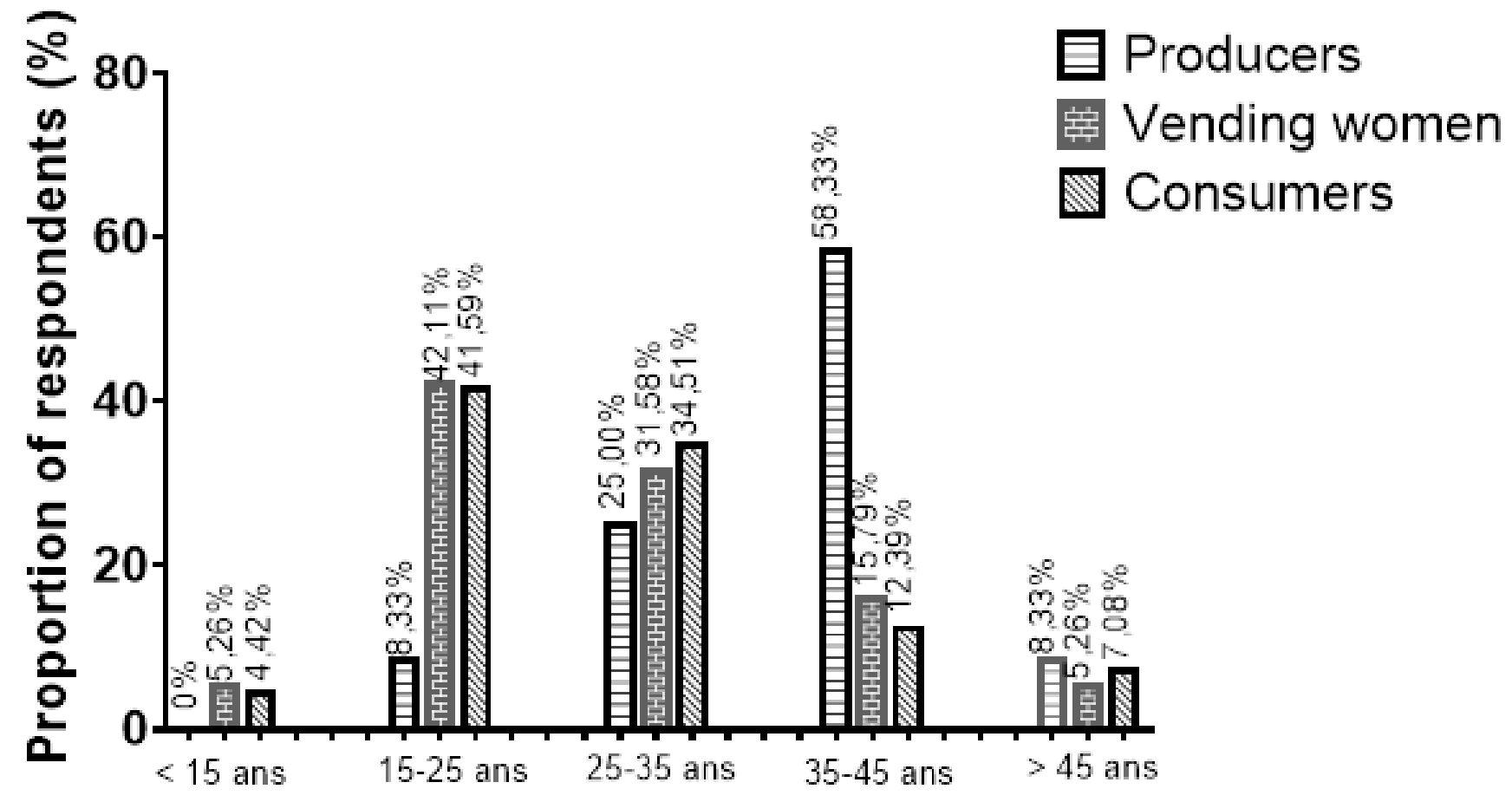

Age ranges of respondents

Figure 9: Distribution of respondents (producers, distributors, and consumers) in by age groups

\section{Age of actors}

All age groups are involved in the production, distribution, and consumption of porridge (Figure 9).

According to Figure 9, the production of porridge concerns more the age group $35-45$ years with $58.3 \%$. This is explained by the fact that this is an activity that is developed by major and often married women who make it a lucrative business.

The 15-25 age group is more engaged in the distribution or sale of this porridge, followed by that between 25 and 35 years of age. This means that the sale of this porridge is done by young actresses in comparison to those of production. This observation can be justified by the fact that, as in the case of many street foods, distribution is carried out in an itinerant way [12] by girls who go from one place to another, to points of affluence such as traffic lights, the beach, churches, markets and other places deemed suitable for sale. This requires more activity and can take all day. Major and married women cannot leave their homes for such a long time. However, vending women encountered in the age groups 35-45 and over were likely to be single or independent of marital responsibility.

With respect to the consumption of the nutsedge-based porridge, all age groups are represented. This means that it is a food that interests both children and adults and views the nutritional value of nutsedge [16], the promotion of the consumption of this porridge is an asset for the health. However, we noted that this porridge is more consumed by young people between 15 and 35 years old. This can be justified by the fact that the surveyed sales sites are more popular with a younger age group. Also, as justified by [17], a good proportion of those who eat on the street are unmarried men under 30, including students. Sales scenes generally take place at the traffic lights at the truck stops, where the sellers rush to the passengers to sell their product. These scenes of winds are also observable at the level of the beach, the harbor area and in some markets.

\section{Gender and marital status of actors}

The production and distribution of porridge is an activity of women who are often married in the case of producers and single women in that of vending one (Table 6). This is consistent with the study of [12], which showed that women are more involved in the processing of local products. However, there has been a proportion, however small, of distributors who are students helping their relatives in the sale of this porridge (Figure 9). More young unmarried women are distributed (Table 6) because, as noted above, as in the case of many street foods, this sale is done in a traveling way [12] and requires more time to 
spend outside the production site.

Consumers are typically men who are forced to consume street food either by moving away from the place of residence or because of lack of time to cook or because of type of activities carried out [17] or for pleasure especially in the case of the nutsedge-based porridge containing sheaves (Table 6).

\begin{tabular}{|l|l|l|l|l|l|l|l|}
\hline & \multicolumn{9}{|c|}{ Sex } & \multicolumn{3}{l|}{ Marital status } \\
\hline \multirow{5}{*}{ Respondents } & & $\mathbf{M ~ ( \% )}$ & $\mathbf{F}(\%)$ & Other (\%) & Married (\%) & Single (\%) & Other (\%) \\
\cline { 2 - 9 } & Producers & 0 & 100 & 0 & 58,33 & 33,33 & 8,33 \\
\cline { 2 - 9 } & Distributors & 5,26 & 94,74 & 0 & 15,78 & 47,37 & 36,84 \\
\cline { 2 - 9 } & Consumers & 83,19 & 16,81 & 0 & 30,97 & 55,75 & 13,27 \\
\hline
\end{tabular}

Table 6: Sex and marital status of respondents (producers, distributors and consumers)

Reasons for the consumption of the edible nutsedges porridge: consumer opinion

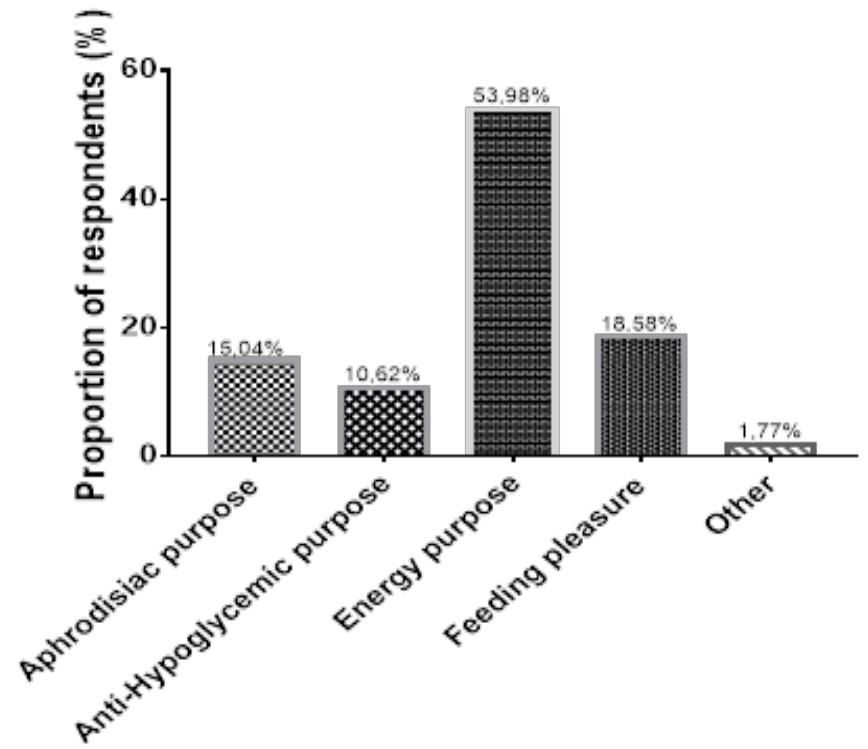

Figure 10: Distribution of consumers of the porridge according to the purposes of consumption.

Beyond food purposes, the consumption of the nutsedge-based porridge has other interests according to the information collected from the consumers surveyed. Indeed, they have stated that by the consumption of energy interests, in most cases (54\%) and for food pleasure (18.6\%), they consume also this porridge for pharmacological purposes such as aphrodisiac (15\%) and anti-hypoglycemic (10.6\%) (Figure 10).

\section{Economic aspect}

The investigation of the frequency of production of porridge has indicated that, overall, they are four productions per week, or sixteen (16) days of production per month. This observation is explained by the fact that on the seven days of the week, the producers use one day to refuel in raw materials and do not produce the non-working days because of low affluence in the places of sale. However, a few produce the Weekends to sell especially Sundays at the level of churches after Mass. Based on 16 actual productions per month, the financial profitability of the production of the slurry was evaluated from the cultivars of stumps. The calculation of depreciation and financial profitability is presented in Tables 7 and 8 respectively.

Thus, the income of a producer of porridge varies depending on whether she is both a producer and a vendor or not. Two cases than appear as follows:

- If the producer ensures the distribution of her own production then, in this case, the entire profit margin (7162, 18175 FCFA), is for her.

- If the distribution of the production is ensured by another person besides the producer, then the profit margin is divided between the two actors. In this case, a dozen dumplings are left at 950 FCFA to the distributors and in the production above there are 9,333 dozen. The distributor will then have to win 2332,5 FCFA is (250 FCFA X 9.333). This amount (2332.5 FCFA) represents $32.5668 \%$ of the profit margin and the $67.4331 \%$ or 4829.68175 FCFA goes to the producer.

\section{Conclusion}

The objective was to investigate different traditional methods for nutsedges porridge production in Togo and aims mainly to contribute to food safety by nutsedges valorization. The survey identified 2 categories of producers. Producers who incorporate other products, such as milk and/or rice and those who produce this porridge only with nutsedges. Results from the survey of producers of porridge show that in the study area, this porridge is a food recognized and produced by women EWE, MINA, and WATCHI. The sale of this porridge is the main source of income for these women. 


\begin{tabular}{|l|l|l|l|l|l|}
\hline Material & Number & Amount & Amortization (years) & Amortization/month (F CFA) \\
\hline Bassin & 2 & 9000 & 5 & 150 \\
\hline Sieve & 1 & 300 & 1 & 25 \\
\hline Sieve & 1 & 400 & 1 & 34 \\
\hline Bowl & 2 & 150 & 1 & 13 \\
\hline Canvas & 1 & 300 & 1 & 25 \\
\hline Hearth & 1 & 2500 & 5 & 42 \\
\hline Pot & 1 & 7000 & 5 & 117 \\
\hline Palette & 1 & 300 & 5 & 5 \\
\hline Filtration system & 1 & 3000 & 5 & 60 \\
\hline Cashier for sale & 1 & 8000 & 5 & 134 \\
\hline Total & 12 & 30950 & & 605 \\
\hline
\end{tabular}

Table 7: Amortization of the material for the production of the nutsedge-based porridge.

\begin{tabular}{|c|c|c|c|}
\hline Operations & Price/Unity for sale & Quantity & Cost (FCFA) \\
\hline Purchase of nutsedges & 1300 FCFA/measure & 2 local measures & 2600 \\
\hline Purchase of sugar & 600 FCFA/Kg & $1 \mathrm{~kg}$ & 600 \\
\hline Purchase of sachets & 250 FCFA/package & 2 packages & 500 \\
\hline Purchase of water & 25 FCFA/Bassin & 2 bassins & 50 \\
\hline Coal & 250 FCFA/package & 1 package & 250 \\
\hline Amortization/Production ${ }^{\star}$ & - & - & 37.8125 FCFA \\
\hline Unput $^{* *}(1)$ & - & - & 4037.815 FCFA \\
\hline Output $^{\star \star \star}(2)$ & - & - & 11200 FCFA \\
\hline Profit margin $(2)-(1)=(3)$ & - & - & 7162.18175 FCFA \\
\hline Rate of return $\frac{(3)}{(1)}=(4)$ & - & - & 1.773 \\
\hline
\end{tabular}

Table 8: Financial profitability of the production of nutsedge-based porridge.

NB: * Monthly depreciation (605 FCFA) divided by the number of productions per month (16);

$* *$ Total expenditure for a slurry production from two measures of slurry ( $6 \mathrm{~kg}$ of porridge);

$* * \star$ Sum generated by the sale of production of porridge from $6 \mathrm{~kg}$ of waste. 


\section{References}

1) Lyonga SN, Nzietcheng S (1987) Cocoyam and the African food crisis. Tropical root crops: root crops and the African food crisis 84-87.

2) Ousseina AD (2012) Etude des Ressources fourragères de la station expérimentale de Toukounous: diversité, structure, dynamique, qualité et disponibilité. Thèse de Doctorat. Université Abdou Moumounou Niamey (Niger).

3) Ekeanyanwu RC, Ononogbu CI (2010) Nutritive Value of Tigernut (Cyperus esculentus L.). Agricultural Journal 5 : 297-302. 4) Odoemelan SA (2003) La composition chimique et les propriétés fonctionnelles de la farine de noix de conophor (Tetracarpidium conophorum). Int. J. Sci. Food Technol 38: 729-734.

5) Belewu MA, Belewu KY (2007) Comparative Physico-chemical evaluation of tiger nut, Soybean, and Coconut milk sources. Int. J. Agric. Biol 9: 785-787.

6) (2012) CRDO Consejo Regulator of the Denominacion d'Origen Chufa de Valencia.

7) Pascual B, Maroto JV, Lopez-Galarza S, Sanbautista A, (Cyperus esculentus L. var. sativus Boeck): (2003) An unconventional crop studies related to applications and cultivation. Econo-Bot 54: 439-48.

8) Ban-Koffi L, Nemlin GJ, LeFevre S, KamenanA (2005) Caractérisation physico-chimique et potentialités thérapeutiques du pois sucré (Cyperus esculentus L. (Cyperaceae)). Agronomie Africaine17: 63-71.

9) Muchnik J (1981) Technologies autochtones et alimentation en Amérique latine; Massy (France) Altersial.

10) FAO. Les aliments vendus sur la voie publique. Rapport d'une consultation FAO d'experts, 5-9 décembre 1988, Yogyakarta, Indonésie. Rome.

11) Hans-Joachim M, Hans-Jurgen W (2002) Insulating container. US Patent App. 09/970,652

12) Njintang YN (2003) Studies on the production of taro (Colocasia esculenta L. Schott) flour for use in the preparation of Achu. Ph.D. thesis, University of Ngaoundéré, National School of Agro-Industrial Sciences (ENSAI) (Cameroon).

13) N'guessan AG, Aboua F, Kouadio K, Kamenan A (1997) Influence of hydrothermal treatments on the physicochemical properties of cocoyam flours; application to the processing of the futu type instant flour. Sci. aliment 17: 35-44.

14) Elkhalifa AE, Schiffler B, Bernhard R (2004) Effect of fermentation on the starch digestibility, resistant starch and some physicochemical properties of sorghum flour. Nahrung 48: 9194.

15) Adjei-Duodu T ( 2014) Physical, Chemical and Functional Properties of Tiger Nuts (Cyperus esculentus) Selected from
Ghana, Cameroon and UK Market (Spain). DOCTOR OF PHILOSOPHY, School of Biological Sciences, Faculty of Science and Environment University of Plymouth Research Theses 254 p.

16) Canet C, N Diaye CL (1996) alimentation de rue en Afrique. FNA/ANA, 17/18 4-13.

17) Akoa Etoa JM, Nossi EJ, Fomba CGN (2008) Mounjouenpou P.Overview of Culinary Preparations Sold in the Major Market of Yaoundé-Cameroon. Journal of culinary science and technology 16: 178-193.

Submit your manuscript to a JScholar journal and benefit from:

I Convenient online submission

ฯ Rigorous peer review

T Immediate publication on acceptance

- Open access: articles freely available online

9 High visibility within the field

ब Better discount for your subsequent articles

Submit your manuscript at http://www.jscholaronline.org/submit-manuscript.php 